Improving school and community partnership for sustainable quality assurance in secondary schools in Nigeria

Ayeni, Adeolu Joshua

Ondo State Quality Education Assurance Agency, Akure, Nigeria (ayeniadeolu@yahoo.com)

Received: 10 November 2011

Revised: 20 January 2012 DOI: $10.5861 /$ ijrse.2012.v1i2.49

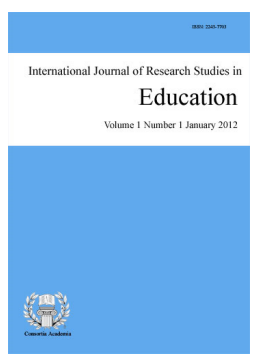

ISSN: $2243-7703$ Online ISSN: 2243-7711

OPEN ACCESS

\title{
Abstract
}

The paper highlights the objectives of secondary education, principal's, teacher's and student's tasks in the attainment of quality education in secondary schools. It also examines the effectiveness of school-community partnership in ensuring quality instructional management, resource inputs, process and students' learning outcomes. The paper concluded that the challenges that principals and teachers faced require effective application of a goal-oriented school and community partnership model as means of improving the quality of teaching and learning for the attainment of the set goals in secondary schools.

Keywords: educational objectives; school-community partnership; sustainable quality assurance; principal's tasks; teacher's tasks; student's tasks; partnership model; learning outcome 


\section{Improving school and community partnership for sustainable quality assurance in secondary schools in Nigeria}

\section{Introduction}

Education is an instrument par excellence and the means of developing human intellect, technical skills, character and effective citizenship for self-reliance and national development. This underscores the value being placed on quality and standards which encompasses quality learning resource inputs, instructional process, teachers' capacities development, effective management, monitoring and evaluation, and quality learning outcome in secondary schools. The quest for quality improvement in education service delivery necessitated the application of quality system management standards in the education sector. The adoption of quality assurance in education as an emerging policy perspective in the contemporary world emanated at the World Conference on Education for All led by UNESCO at Thailand in 1990. Representatives of the international community agreed that all countries should pay greater attention towards improving all aspects of the quality of education and ensuring excellence of all. This is to ensure substantial achievement of recognized and measurable learning outcomes in schools, especially in literacy, numeracy and essential life skills (UNESCO, 2002). Quality assurance, therefore, is one of the most critical tasks facing every nation's educational institutions, so that the societal demands for improved education service delivery would achieve the best learning outcomes that enhance the quality of life of the citizenry (Ayeni, 2010).

The World Declaration on Education for All was re-affirmed by the international community in Dakar, Senegal in 2000. In pursuit of the goals set at the Conference, the United Nations member states agreed to show maximum commitment to the implementation of the Millennium Development Goals (MDGs) adopted at the Millennium Summit held in New York in September, 2000. The United Nations Millennium Declaration recognized education as a key component and the need for every nation to use it as a veritable tool to significantly improve human, social and economic conditions by 2015. The current global moves towards ensuring that educational systems meet the MDGs, the challenges of information and communication technology (ICT), the evolution of the global digital economy, and the global competition for technically skilled workers underscores the priority being given to quality assurance in education as an instrument for achieving sustainable development of human potential in particular and Nigeria's economy as a whole (Federal Republic of Nigeria, 2004; Federal Ministry of Education, 2009).

Sustainable quality assurance in secondary education is a continuous process of best practices in the management and utilization of human and material resources, facilities, finance, and development of positive corporate culture and strategic supervision of teaching and learning activities for the realization of the set goals in schools (Ayeni, 2010). Sustainable quality assurance in an educational institution is also made possible when every member of the institution contributes his/her quota to the quality process (Venkaiah, 1995; Zuhari \& Suparman, 2002). All these are required to ensure a complete well-rounded education and production of quality students and consistent improvement in secondary school system.

\section{School and Community Partnership Building}

School and community partnership is a two-way process of relationship in which members of the school and communities share common values, aspirations, beliefs, responsibilities, obligations and develop mutual respect, understanding and ways of working together to ensure effective management, instructional practices and improvement in students' learning outcomes. The partnership enables the community members and agencies to help schools with extra learning resources, enabling environments, build teachers' capacities by coopting competent and professional educationists from the community into the school-based teacher development committee to help improve teachers' capacities for effective instructional performance and improvement in 
students' academic performance.

The school is a planned social organization that acts as an instrument of the society for teaching the young ones and thrives on effective interrelationships within it and with its relevant publics. The school requires a lot of human, materials, physical facilities and financial resources for building the capacity of the education system to be able to deliver high quality and relevant curriculum to learners of all ages. In meeting this demand, the members of the community who have personal, educational, professional, social, cultural, linguistic and economic life experiences provide volunteer roles and a variety of learning opportunities and positive learning environments to improve curriculum delivery and students' learning outcomes. The partnerships are made functional and result-oriented through periodic meetings, seminars, workshops, conferences, special events, feedback, home contacts, inter-visitation and policy reviews based on agreed criteria among members of the school and host communities.

School-community partnership is a driving force behind quality assurance practice, aimed at improving the quality of school management, learning environment, curriculum delivery and students' learning outcomes through the involvement of meaningful, close, strong and goal-oriented partnership between the school authority and other relevant stakeholders (Parent-Teachers Association (PTA), Old Students Association, Non-government agencies, Communities, Ministries, School Board, Individuals and other social institutions). This synergy is necessary because a virile and responsive school-community relationship is a building block for the attainment of specified standards and set goals and production of quality outputs that will satisfy the expectations of the institution's customers/society (Ayeni, 2010).

\section{Objectives of Secondary Education}

The secondary school system as contained in the National Policy on Education (Federal Republic of Nigeria, 2004) aptly states that the broad objectives of secondary education in Nigeria are: 1.) preparation of students for useful living within the society; and 2.) preparation of students for higher education. Specifically, the secondary school system is geared towards catering for the differences in talents, opportunities and future roles; provide trained manpower in the applied science, technology and commerce at sub-professional grades; develop and promote Nigerian languages, art and culture in the context of world's cultural heritage; inspire students with a desire for self improvement and achievement of excellence; foster national unity with an emphasis on the common ties that unite us in our diversity; raise a generation of people who can think for themselves, respect the views and feelings of others, respect the dignity of labour, appreciate those values specified under our broad national goals and live as good citizens; and provide technical knowledge and vocational skills necessary for agricultural, industrial, commercial and economic development (Federal Republic of Nigeria, 2004).

The objectives of secondary education make it clear that the future of the nation (Nigeria) depends quite considerably on the quality of education it provides for its citizens. The realization of these objectives hinges on quality of teachers, infrastructure and learning environment, resource inputs, teaching process, classroom management, academic assessment, principals' supervision roles and students' commitment to learning (Ayeni, 2010). Ravitch (2000) while stressing the need to provide standard-based and sustainable quality education for American high school students, stated that schools across the country must establish high academic standards, and must be accountable for teaching specified levels of content to all the children they enroll in order to ensure socio-economic and political well-being of the citizenry, which depends on what is learned in schools. This underscores the significance of quality assurance in education to human capital development for sustainable self-reliance of the individual and the overall development of the nation for mutual benefit of the citizenry.

The quality of performance of training institutions in human capital development is determined by the activities of the institutions themselves. A well-planned curriculum program that allows community participation in the monitoring and evaluation of instructional activities can support effective teaching and learning if directed toward the set educational goals in schools. Adetula (2005) reporting on some studies carried out in Europe, 
America (Canada and U.S.A.) and Australia, identified the main goals of school supervision to include: to seek insight into leadership process, motivational forces, decision-making processes, goal-setting processes, team work and group interaction which in turn lead to effective and functional schools. Adetula's study corroborated the present study which intends to examine the school and community partnership in the teaching- learning process with a view to ensuring sustainable quality assurance in secondary education.

\section{Principals', Teachers' and Students' Tasks in Quality Assurance}

Principalship is a well established position of the chief executive who performs staggering range of roles that are enormously complex and multi-tasking ( psychologist, teacher, facilities manager, philosopher, security officer, diplomat, social worker, mentor, public relation director, coach, cheer leader etc ); provides instructional leadership by coordinating curricula, co-curricular programs and is responsible for the general administration of the secondary school. The principals being instructional leaders are at the vantage positions to supervise, monitor, assess, evaluate and disseminate current information on educational issues and modern teaching techniques to teachers in order to stimulate them for scholarship and best practices in curriculum delivery.

Quality assurance is achieved in schools that have principals who are result-oriented and adopt strategic planning approach in resource and curriculum management; such principals are highly visible in the school and stay close to the instructional process. In many instances, effective principals adopt continuous and consistent classroom visitation to ensure adequate teaching and learning processes (Peters \& Waterman, 1988). At the same time, instructional leadership is in many ways a shared responsibility. It engenders a common sense of commitment and collegiality, and expands the resources and pool of knowledge among the staff.

Quality Assurance school principals establish clearly defined goals for academic achievement, and they concentrated their available resources and their operations on attaining them, provide adequate time-table for teaching, routine check of lesson notes and subject dairies, observation of classroom instruction, continuously monitor students progress to determine whether their instructional goals are being met, provide feed-back on student performance, motivation of teachers for improved performance, reinforcement of students for excellent performance, maintenance and appropriate usage of physical facilities, enforcement of discipline to ensure peaceful atmosphere, capacity building of teachers for effective service delivery, provision of instructional facilities and materials, motivating teachers for optimum productivity and building synergy with relevant stakeholders to enhance quality teaching-learning processes (Ayeni, 2010). Similarly, the teachers are expected to provide essential inputs like adequate planning of lesson notes, effective delivery of lessons, proper monitoring and evaluation of students' performance, providing regular feed-back on students' performance, improvisation of instructional materials, adequate keeping of records and appropriate discipline of students to produce and enhance expected learning achievement in secondary schools (Ayeni, 2010).

The students on their own end are not dormant in the quality assurance process as they are expected to attend classes punctually and regularly, possess necessary learning materials, develop good reading culture, participate actively in class exercises and take-home assignments, cultivate sustainable interest in co-curricular activities and demonstrate cordial and positive inter-personal relationships in order to achieve the expected learning outcome in schools (Ayeni, 2010). However, the inability of successive administrations in Nigeria to adequately fund education over the years led to the systemic mal-functioning of the school system, Consequently, there is a growing public outcry about the realization of secondary education objectives; this has been attributed to gaps in teachers' competence, curriculum instruction, learning facilities and resources, funding, institutional management and ineffective supervision of instructional activities by the inspectorate department and many principals in secondary schools. The resultant effect is the poor teaching and learning that culminated into a large scale examination malpractice and abysmal performance of students in external examinations, which depicts non-realization of sustainable quality assurance in teaching and students' learning outcomes in secondary schools (Adeniji, 2002; Ogunu, 2001). These challenges prompted the Ondo State Government to blaze the trail in the establishment of an autonomous Quality Education Assurance Agency and still remain the only state with 
an autonomous Agency in Nigeria.

\subsection{Trends in Students' Academic Performance}

The results of Senior School Certificate Examination conducted by the West African Examination Council (WASSCE) and the National Examination Council (NECOSSCE) were extremely poor in Nigeria between 2007 and 2010. The percentage of students who obtained credit level passes in five subjects and above including English Language and Mathematics was about $25 \%$ in Nigeria while in Ondo State, students' results in WASSCE between 2007 and 2009 ranged from 16.7\% to $19.1 \%$ and the same in NECOSSCE ranged from $3.2 \%$ to $27 \%$ and $35 \%$ in 2010 (Bello-Osagie \& Olugbamila, 2009; Owadiae, 2010; Quality Education Assurance Agency, 2010). Also in 2011 May/June Senior School Certificate Examination conducted by the West African Examination Council, only $30.99 \%$ of the 1,540,250 candidates obtained credit level passes and above in five subjects including English Language and Mathematics, while in the 2011 June/July NECOSSCE, only $22.34 \%$ of the 1,160,561 candidates obtained credit level passes and above in English Language subject and 25.14\% in Mathematics subject in the 36 States of the Federation, and the Federal Capital Territory (Owadiae, 2011; Okpala, 2011).

The abysmal performance of students in examinations had also been largely attributed to inadequate learning facilities (Earthman, 2002). This situation has been a source of concern to the school administrators, government and other stakeholders. According to Fafunwa (2010), there is a big gap in quality, resulting from large number of students in crowded classrooms, using inadequate and obsolete equipment and with disillusioned teachers. These combined deficiencies perhaps constituted a major gap in the quality of learning facilities, thus, many challenges bear on teaching and learning that prevent the education system from getting the best out of its efforts to achieve the required level of attainment in teaching and learning activities in secondary schools. A consideration of the above shows that there is a greater challenge ahead of principals, teachers and other stakeholders partly because of existing gaps and inadequacies in their instructional and supervisory duties, and low level of commitment to schools' program activities and development.

\subsection{Components of School Quality Assurance Process}

In meeting the task of monitoring and evaluation of quality of curriculum delivery and students' learning outcomes, Abolade (2007) identified the main components of school quality assurance process as follows: 1. ) Systematic monitoring and observation of the core activities of a school especially teaching and learning; 2.) Collection and storage of data collected from monitoring activities; 3.) Collation and evaluation of data collected to make decisions about maintaining, modifying, accepting or rejecting program particularly on curriculum issues, teachers' instructional styles, students' abilities, needs and behaviors as well as textbooks, organizational structure or personnel; 4.) Implementation of necessary remedial action to improve teachers' pedagogical practices and students' learning outcomes; and 5.) Feed-back to all stakeholders affected by the program in order to ensure quality with public accountability and consistent review of performance and evaluation procedures, to bring about continuous improvement in teaching and learning processes in schools.

The performance of these activities was further stressed by Ayeni (2010) as the core responsibility of the head-teacher who is the driving force behind the school program to clearly define the goals, mobilize all members of staff towards effective service delivery and adequate keeping of records; so as to provide necessary information to the commitment-holders: governing board, parents and the community towards identifying the school strengths and weaknesses, evaluate and review of the school policies, program and activities so as to take appropriate decisions on type of follow-up action required to improve resource inputs, teachers' competence and students' learning activities for the attainment of goals set and sustenance of integrity and accountability in quality assurance practice. This shows that quality assurance is a collective responsibility of all the commitment-holders in education. 


\subsection{School and Community Partnership Model of Quality Assurance}

It is clear that the complex task of the principal is how to organize the school to meet the various challenges facing school administration and curriculum delivery so that the education aims and objectives can be achieved. This situation calls for an improvement in the system approach in practice; an attempt has therefore been made to build school-community partnership model of education quality assurance for the operation of the school system to achieve desired quality in teachers' instructional task performance, principals' supervisory roles and students' academic performance. The operational structure and components of the school and community partnership model of education quality assurance is explained diagrammatically below:

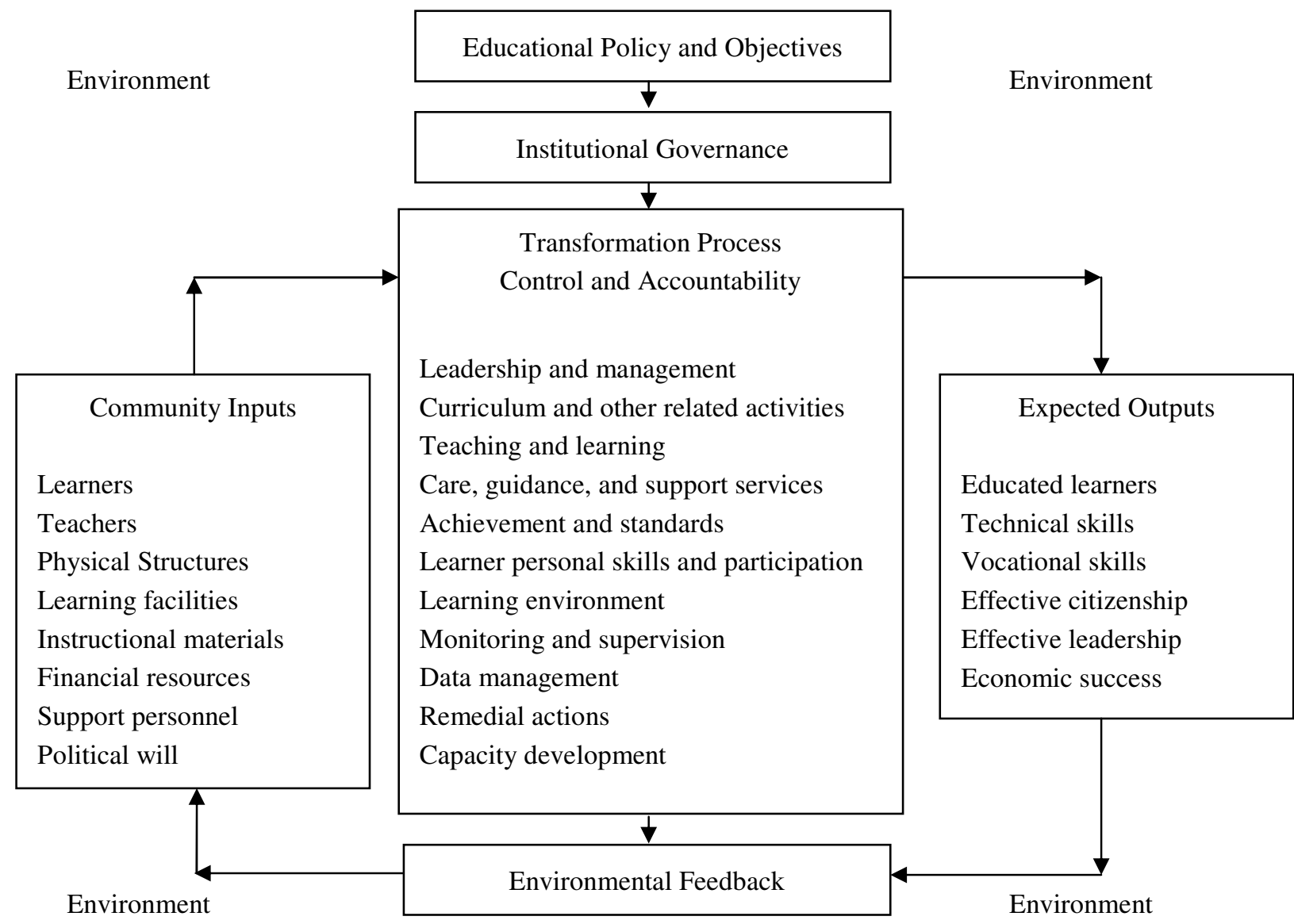

Figure 1. School and community partnership model of education quality assurance

In pursuit of quality assurance within the context of the school and community partnership model, Ayeni (2010) views the school as an open system that maintains a network of relationships among individuals and activities within it, and continuously inter-relate with the external environment, particularly the stakeholders who formulate the National Policy on Education that provides the objectives and operational guidelines for the principal to implement. In a bid to translate the educational objectives into reality, the principal relates with the stakeholders and seeks for inputs in form of human resource, finance, facilities and materials; these are transformed through teaching and learning processes while the principal ensures effective organization, utilization, supervision and management of curricula and co-curricular activities, and public accountability in the use of resources geared towards quality development of the learners that occupy the centre stage of the educational system and no doubt remain the largest and most crucial input of the school.

At the successful completion of their education, the learners are released as outputs into the environment (society). This underscores the reason for making education the child centered in order to ensure quality human capital development for sustainable self-reliance of the individual and the overall development of the nation for 
mutual benefit of the citizenry. The school can also achieve a dynamic recycling process in the resource-feedback from the environment to the school through sustainable inter-dependent relationship between it and the community, by promoting good value system and recognizing the cooperation, participation and support of significant and relevant stakeholders in the management of school resources. This cyclical relationship process strengthens the community mandate in education and instills sense of collective ownership, responsibility and commitment to the progress of the school's program, activities, development of physical structures, learning facilities and improvement in learning outcome. This is a pro-active means of achieving the desired goals in community inputs, instructional process and outputs in secondary schools.

\subsection{Benefits of Quality Assurance-oriented School and Community Partnership}

The opportunities that are inherent in quality assurance-oriented school and community partnership are highlighted by Ayeni (2010) as follows:

> Improvement in the school and community partnership will contribute to the growing body of knowledge on educational effectiveness and teacher quality. The emphasis placed on teachers' pedagogic practices and students' learning processes will enable members of the community, teachers and students to have clear information about learning outcomes and develop strong commitment to the achievement of educational goals.

It is expected that the emphasis being placed on quality assurance will raise the level of awareness of principals and members of the community with regard to adequate provision of suitable teaching materials/facilities, conducive working environment, capacity building of teachers, non-academic staff and students welfare and promote cordial interpersonal relations between members of the school and communities to facilitate effective curriculum implementation and quality learning outcome in secondary schools.

$>$ It is envisaged that the quality assurance practice will encourage school principals and members of the community to pay special attention to their roles in institutional management and enable them evaluate their school program and to establish procedures that would help those teachers and students that do not perform well in order to achieve optimum productivity and quality learning outcome. This will provide teachers with relevant information on the effects and efficacy of their teaching pedagogy and stimulate them for better performance.

> Quality assurance based school and community partnership will generate information on students' performance that will facilitate greater synergy among stakeholders in education to find solutions to problems of quality in secondary education; so that academic norms are not undermined at the expense of social norms, but both would complement each other. This will also highlight the weaknesses inherent in the leadership behavior of principals and stimulate government and other stakeholders to see the need for capacity building of secondary school principals in order to improve institutional management and instructional supervision in secondary schools.

\section{Conclusions}

The paper concluded that school and community partnerships are vital for school effectiveness and students' success, while the challenges that principals and teachers faced in the tasks of supervision and instructional task performance require more commitment and goal-oriented partnership between the school and other stakeholders in order to improve learning facilities, curriculum delivery and students' learning outcomes in secondary schools. The following recommendations are made in order to improve teaching-learning process, instructional supervision and institutional management for the achievement of the set goals and production of quality outputs (students) that meet the expectations of the community. The school principals should provide constant and adequate feedback to the teachers on their instructional task performance to ensure periodic review and 
determine specific training needs of teachers for further partnership of the communities in teachers' capacities development and improvement in the teaching-learning process in secondary schools. The school authority should provide timely feedback on students' academic performance to parents in order to sensitize and encourage them to provide the required textbooks and other learning materials for their children/wards. The financial resources needed to ensure adequate provision of learning resources and grant- in-aids for proper maintenance of the facilities should be provided through increase in budgetary allocation, internally generated revenue and community support, so as to create good and sustainable working climate for effective teaching and learning processes in secondary schools. All the stakeholders in the education sector should pro-actively collaborate to organize annual education summit for comprehensive review and assessment of the degree of success and challenges in producing the desired outputs. The purpose is to achieve the overall educational objectives and ensure sustainable improvement in resource inputs, institutional management, curriculum delivery and quality outputs in secondary schools.

\section{References:}

Abolade J. O. (2007). Whole school evaluation. Paper presented at the Induction and Re-orientation Workshop for Federal and State Inspectors of Education, Akure.

Adeniji, I. A. (2002). Perception of principals and teachers of external supervisors' role in secondary schools in Ogun State. Nigerian Journal of Clinical and Counseling Psychology, 8(1), 43-56.

Adetula, L. O. (2005). Improving the supervisory skills and competencies of inspectors of mathematics education in schools. International Journal of the Teachers Registration Council of Nigeria, 1(1), $33-40$.

Ayeni. A. J. (2010). Teachers' instructional task performance and principals' supervisory roles as correlates of quality assurance in secondary schools in Ondo State. Unpublished doctoral dissertation, Obafemi Awolowo University, Ile-Ife, Nigeria.

Bello-Osagie, K., \& Olugbamila, A. (2009, December 31). Events that shape education. The Nation, p. B2.

Earthman, G. I. (2002). School facility conditions and student academic achievement. Los Angeles: University of California's Institute for Democracy, Education and Access. <http://www.ucla-idea.org >

Fafunwa, A. B. (2010, October 13). Fafunwa's last interview: Remember me as somebody who promoted use of mother tongue in schools. The Punch, p 3.

Federal Ministry of Education. (2009). Repositioning the Nigerian education sector. Newsletter, 23, 27-28.

Federal Republic of Nigeria. (2004). National Policy on Education. Lagos: NERDC Press.

Ogunu, M. A. (2001). Problems of school inspection in Nigeria in current issues in educational management in Nigeria. In Nigeria Association of Educational Administration and Planning (pp. 270-281), Nigeria.

Okpala, P. M. (2011, September 24). Mass failure as NECO releases results. The Nation. p.6.

Owadiae, I. (2010, August 31). West African Senior School Certificate Examination result. The Punch, p. 39.

Owadiae, I. (2011, August, 11). West African Senior School Certificate Examination result. The Nation, p. 4.

Peters, T. J., \& Robert Jr., H. W. (1988). In search of excellence: Lesson from American's best run companies. New York: Harper and Row.

Quality Education Agency. (2010). Analysis of results of WAEC/NECO Senior Secondary School Certificate Examinations. Ondo state, Nigeria.

Ravitch, D. (2000). Left back: A century of failed school reforms. New York: Simon \& Schuster. UNESCO. (2002), Nigeria private sector and education for all. Abuja: UNESCO Publication.

Venkaiah, V. (1995). Quality assurance in student support services. In M. S. Rao, G. Srinivasacharyulu, and J. Mohanraj (Eds.), Quality assurance in distance education (pp. 151-159). India: D. K. Fine Art Press Limited.

Zuhari, A., \& Suparman, A. (2002). Managing quality and accessibility in open and distance learning. In Dkshit, H. P. (et. al). Access and equity (p. 262). New Delhi: Kogan Page. 